\title{
Life-history traits of Amur sleeper, Perccottus glenii, in the invaded Vistula River: early investment in reproduction but reduced growth rate
}

\author{
Grabowska Joanna • Pietraszewski Dariusz • \\ Przybylski Mirosław - Tarkan Ali Serhan • \\ Marszał Lidia • Lampart-Kałużniacka Magdalena
}

Received: 22 April 2010/Revised: 4 October 2010/Accepted: 13 October 2010/Published online: 1 November 2010

(C) The Author(s) 2010. This article is published with open access at Springerlink.com

\begin{abstract}
In recent decades, Amur sleeper is one of the most invasive fish species in Eastern and Central Europe. Generally, it is assumed that success of an invasive species can largely depend on the plasticity of its life-history traits, e.g., indicated by higher investment in reproduction in the initial stage of its invasion. On the other hand, such energy allocation to production of gonads should negatively impact somatic growth rate. The aim of this article was to explore this phenomenon in a non-native population of Amur sleeper inhabiting artificial reservoir on a large lowland river in Central Europe. Through analysis of the population age structure, sex-dependent growth rate and life-history traits we assessed investment in reproduction and its possible relationship with growth pattern as well as compared the
\end{abstract}

Handling editor: M. Power

G. Joanna $(\bowtie) \cdot$ P. Dariusz · P. Mirosław · M. Lidia Department of Ecology and Vertebrate Zoology, University of Lodz, Banacha 12/16, 90-237 Lodz, Poland e-mail: joko@biol.uni.lodz.pl

T. A. Serhan

Muğla Universitesi Su Urunleri Fakultesi, 48000 Kötekli, Muğla, Turkey

\section{L.-K. Magdalena}

Department of Environmental Biology, Technical University of Koszalin, Śniadeckich 2, 75-453 Koszalin, Poland results with literature data from native and introduced range. Samples collected monthly from April 2005 to March 2006 were used to estimate sex ratio, GSI, fecundity, eggs diameter frequency over the year, duration of spawning season, and mode of spawning. Age structure was calculated from scales and the same data were also used to back-calculate standard length (SL) at age. The population in the Włocławski Reservoir was represented by eight age groups, and its life span was one of the longest recorded both in its natural range and introduced areas. The weightlength relationship showed that the Amur sleeper grew isometrically and there was no difference between females and males. Although the Amur sleeper growth rate was relatively slow in the Włocławski Reservoir, its increment in the first year of life was comparable to that in other introduced areas and higher than in its natural range. The female age of maturation $(1+)$ found in the reservoir was earlier than observed in its natural range as well as in most introduced areas $(2+, 3+)$. Female length at maturation was similar to that reported elsewhere. The back-calculated standard length (SL) of females and males showed that in the first two age classes (1 and 2) males achieved larger SL than females. Meanwhile, at age 3, 4 and 5, females were larger than males but these differences were insignificant, except for class 5 . For both sexes the average annual increment of SL decreased with age but in females the increment was always higher than in males $(P<0.05)$. The growth rate differences between 
females and males resulted possibly from their unequal investment in reproduction. Multiple spawning in the Włocławski Reservoir lasted from April to the end of August and was almost 3 months longer than in other regions. Thus, this higher investment in reproduction displayed by, e.g., earlier maturation of females and longer spawning season in the Włocławski Reservoir, may contribute to invasive success of Amur sleeper in newly colonized areas; however, the costs of this strategy result in slower growth in older age classes.

Keywords Alien fish - Invasions · Growth · Reproduction

\section{Introduction}

Species with wide range distributions display a great variation in life-history traits, which are responses to local environmental conditions (Svardson, 1949; Southwood, 1988). In many cases, such variation shows a geographical pattern (Mann et al., 1984; Vollestad \& L'Abbe-Lund, 1990). The strong effect of local environmental conditions on life-history strategy modifications was well documented in a bullhead (Cottus gobio) reciprocal transfer experiment (Mann et al., 1984). Species invasions far beyond their native regions are a kind of unintentional natural experiment which give an particular opportunity to show the phenotypic plasticity of lifehistory traits among geographically distant populations exposed to different environmental conditions (Rice \& Sax, 2005; Villeneuve et al., 2005; Fox et al., 2007; Kováč et al., 2009; Ribeiro \& Collares-Pereira, 2010). Furthermore, life-history traits may shift over time in the same introduced population, e.g., from an early invasion stage soon after species arrival until the population becomes well established (Bøhn et al., 2004; Fox et al., 2007; Britton et al., 2008). Thus, it has been hypothesized that the success of an invasive species can be strongly dependent on the plasticity of its life-history traits (Fox et al., 2007; Ribeiro \& Collares-Pereira, 2010).

The Amur sleeper (Odontobutidae, Perciformes), or rotan (see Bogutskaya \& Naseka, 2002; Reshetnikov, 2004) is one of the most invasive fish species in Eastern and Central Europe of recent decades (Copp et al., 2005). The species originates from the Far East Asia (Miller \& Vasil'eva, 2003), and was initially brought in 1912 to St. Petersburg and then to the Moscow area in 1948. It soon spread and was reported from many other localities in the former Soviet Union (Litvinov \& O’Gorman, 1996; Bogutskaya \& Naseka, 2002; Reshetnikov, 2004). In the Central Europe, it was recorded in the Vistula River basin in 1988 in Ukraine (Movchan, 1989) and later in 1993 in Poland (Antychowicz, 1994, Terlecki \& Pałka, 1999). Since the late 1990s, it has been found in several locations in the Danube River and/or its tributaries in Hungary (Harka, 1998), Slovakia (Kautman, 1999; Koščo et al., 1999), Romania (Nalbant et al., 2004), Serbia (Šipoš et al., 2004), and Bulgaria (Jurajda et al., 2005). In the North, it was noted in Gulf of Finland (Orlova et al., 2006) and in the Arkhangelsk Province of Russia (White Sea basin) (Reshetnikov, 2004). Its accelerated expansion was documented at several occasions as connected with Asian cyprinid stocking (Litvinov \& O'Gorman, 1996; Reshetnikov, 2004).

Although the role of human-mediated factors was crucial for the extensive expansion of the Amur sleeper, it seemed to be especially important only in the first stage of invasion episode, i.e., introduction. The biological features of the Amur sleeper facilitated its establishment and spread from the initial areas of introduction. On many occasions, the rapid increase of Amur sleeper abundance was observed soon after introduction (Bogutskaya \& Naseka, 2002; Koščo et al., 2003a). After its first record in Poland in 1993 (Antychowicz, 1994), the Amur sleeper very quickly spread along the Vistula River and locally it became a dominant fish species (Grabowska et al., 2009). While the expansion of Amur sleeper in Europe is well documented, the most of available data of its life-history come from the native range and several localities of the fish introductions in Russia (see Bogutskaya \& Naseka 2002, for review).

There is only one paper analyzing the growth of this alien species in Central Europe (Koščo et al., 2003b) but there are no data on the other aspects of its life history. In this article, we fill this gap. Our aim was to describe the age structure, growth rate and life-history traits (age and length of maturity, fecundity, GSI, duration of spawning season and mode of spawning) of the Amur sleeper in the lower Vistula 
River, Poland, with implication to its invasive potential.

\section{Materials and methods}

Fish were collected in the Włocławski Reservoir, located in the lower section of the Vistula River (Baltic basin, Poland). This river drains a surface area of $194,424 \mathrm{~km}^{2}$ over its $1047 \mathrm{~km}$ length. The Włocławski Reservoir, located $617 \mathrm{~km}$ downstream from the river source, is a riverine in character, with a width of $1.2-1.4 \mathrm{~km}$, a surface area $70.4 \mathrm{~km}^{2}$ and total volume of $387.2 \times 10^{6} \mathrm{~m}^{3}$. Samples were taken at a site situated on the southern bank of the reservoir (N52 $32^{\prime} 58^{\prime \prime}$; E19 $34^{\prime} 29^{\prime \prime}$ ), where two small inflows of the reservoir form extensive bays sheltered by peninsulas from the main water current. This location was characterized by stagnant water, a sandy substrate with thick layer of mud, and dense areas of submerged and emergent vegetation (Elodea canadensis, Potamogeton perfoliatus, Phragmithes communis, Typha sp., Carex sp.). The Amur sleeper was the dominant species in the sample site. Other species present were Eurasian perch Perca fluviatilis, roach Rutilus rutilus, spined loach Cobitis taenia, bitterling Rhodeus amarus, stickleback Gasterosteus aculeatus, racer goby Neogobius gymnotrachelus as well as single individuals of the chub Leuciscus cephalus, ide Leuciscus idus and pike Esox lucius. Fish were collected in the littoral zone at a depth 0.5 to $1.7 \mathrm{~m}$ by electrofishing with a battery-powered unit $(350 \mathrm{~V}$, 20-100 Hz). Samples were collected monthly from April 2005 to March 2006. In the laboratory, Amur sleepers were weighed (nearest $0.01 \mathrm{~g}$ ), and measured for total length (TL, nearest $\mathrm{mm}$ ) and standard length (SL).

To examine age and growth parameters, scales of 135 specimens collected in October and December 2005 were taken from between the lateral line and first dorsal fin. Age was determined from acetate impressions of scales, read on a micro-projector (magnification: $48 \times$ and $24 \times$ ), with annuli identified using criteria of Steinmetz \& Müller (1991). The number of true annuli was interpreted independently by two researchers. Samples with ambiguous age readings (less than 6\%) were not used in age and growth analysis.
Back-calculation of SL at age was undertaken using the linear relationship between scale radius and SL (Francis, 1990) and the regression for this relationship was $\mathrm{SL}=4.156+8.094 \times R, r^{2}=0.590, n=116$. Back-calculated standard lengths were compared between sexes by nested ANOVA (Zarr, 1984). To describe growth pattern of all specimens as well as separately for males and females, we used the von Bertalanffy and Gompertz models (Ricker, 1975; Bagenal \& Tesch, 1978). Parameters for this model were based on the back-calculated data and were determined with FiSAT software (Gayanilo et al., 1994). The von Bertalanffy growth function was:

$L_{t}=L_{\text {inf }}\left(1-\exp \left(-k\left(t-t_{\mathrm{o}}\right)\right)\right)$

where $L_{t}$ is standard length (mm), $t$ is age (years), $L_{\mathrm{inf}}$ is the asymptotic standard length $(\mathrm{mm}), t_{\mathrm{o}}$ is the origin of the growth curve, and $k$ is the rate at which the asymptotic length is approached. Because $L_{\text {inf }}$ is negatively related to $k$ parameter (Moreau et al., 1985 ) the index of growth performance $\varphi^{\prime}$ (Munro \& Pauly, 1983) was calculated as:

$\varphi^{\prime}=\log _{10}(k)+2 \times \log _{10}\left(L_{\text {inf }}\right)$

The Gompertz growth function used was:

$W_{t}=W_{0} \exp (G(1-\exp (-g t)))$

where $W_{t}$ is weight $(\mathrm{g}), t$ is age (years), $W_{0}$, is weight at the conventional time $t_{0}, G$ is the instantaneous growth rate at time $t_{0}$, and $g$ describes the rate of decrease of $G$. The fish weight in each year of life was estimated from the length-weight regression, calculated at the end of a growth season, i.e., October and December. The parameters of this growth model and their standard errors were calculated using nonlinear regression (Statistica 6.0). To compare the Amur sleeper growth in different locations the standard growth curve was obtained and the relative growth index was calculated (Hickley \& Dexter, 1979).

Gonads of each individual were inspected to determine the sex and sex ratio variation over the year. Only females were used to assess reproductive traits. The gonads of 263 females and 121 males were dissected out and weighted to nearest $0.001 \mathrm{~g}(\mathrm{Wg}$ ). The gonadosomatic index (GSI) was defined as $\mathrm{GSI}=100 \mathrm{Wg} / \mathrm{W}$. The diameter of $\sim 50$ randomly sampled oocytes from each of females were measured 
on a binocular microscope (magnification: $16 \times$ ) and then pooled data were used to determine the size frequency for consecutive months over the year. The fecundity of 60 females collected from April to August 2005 was estimated as the number of yolked eggs (i.e., of diameter larger than $0.36 \mathrm{~mm}$ according to Travkina (1997) since at this stage, the cytoplasm of an oocyte becomes gradually filled with yolk vesicles).

Age at maturity was calculated from mature females in each age-class using the DeMaster's formula (1978), as adapted by Fox (1994):

$\alpha=\sum_{x=0}^{w}(x)[f(x)-f(x-1)]$

where $\alpha$ is the mean age of maturity, $x$ is the age in years, $f(x)$ is the proportion of fish mature at age $x$, and $w$ is maximum age in the sample. Age of females was determined from scales as described above. Female were considered as mature if yolked eggs were present in gonads. Length at maturation was determined using a modification of this formula, with $10 \mathrm{~mm}$ length intervals in place of age classes (Tripple \& Harvey, 1987).

\section{Results}

Age and growth

Among 602 fish collected between April 2005 and March 2006, 275 individuals were identified as females, 250 as males and 77 as juveniles too young to be sexed. The overall sex ratio did not differ from parity $(1: 1, z=1.091 ; P=0.8624)$. Standard length ranged from 35 to $142 \mathrm{~mm}$ for females and 47 to $130 \mathrm{~mm}$ for males. The relationship between TL and SL was described by equations: $\mathrm{TL}=1.14 \mathrm{SL}+$ $3.39 ; r^{2}=0.994$ for females and $\mathrm{TL}=1.13 \mathrm{SL}+$ $4.71 ; r^{2}=0.970$ for males.

The Amur sleeper population in the Włocławski Reservoir was represented by eight age groups from $0+$ to $7+$ (Table 1). Age 5+ individuals dominated in the population, representing $26 \%$ of all individuals sampled.

The back-calculated standard lengths at age are presented in Table 1. The nested ANOVA revealed significant differences in SL between sexes $\left(F_{2 ; 36}=\right.$
11.795; $P=0.0001)$ and age nested in sex $\left(F_{11 ; 36}=\right.$ 63.473; $P<0.0001$ ). Post-hoc comparisons (the Tukey test) showed that at the first two age classes (1 and 2) males achieved larger SL than females (Table 1). Meanwhile, at age 3, 4, and 5, females were larger than males but these differences were insignificant (Table 1). For both sexes combined the average annual increment of SL decreased with age but the females increment was always higher than males one $(P<0.05)$.

The von Bertalanffy growth function well fitted the back-calculated length at age data for both sexes as well as pooled data which was confirmed by high values of coefficient of determination (Table 2) and was in agreement with Taylor's (1962) criterion. According to it, the maximum observed length should constitute approximately $95 \%$ of the estimated asymptotic length $L_{\text {inf. }}$ The maximum observed SL for females was 142 and $130 \mathrm{~mm}$ for males which constituted 78.2 and $92.1 \%$ of the females and males, $L_{\text {inf }}$, respectively. Thus, the model was suitable for males but slightly overestimated for females and pooled data $\left(78.2 \%\right.$ of $\left.L_{\text {inf }}\right)$.

The parameters of von Bertalanffy model revealed sexual differences in length at age. The female asymptotic length was significantly higher than that of males $(t=14.89, P<0.0001)$, but the differences between sexes in $k, t_{\mathrm{o}}$ and $\varphi^{\prime}$ were not significant.

The Gompertz function provided a good fit for the females and both sexes combined, but the parameters estimated for males had very large asymptotic standard errors (Table 2). In such situation, comparison between sexes was not done as it would be considered unreliable.

The regression of fish body weight on SL $\left(\log _{10}\right.$ transformed data) showed that Amur sleeper growth was isometric $(b=3)$ and there was no difference in slope between females and males $(t=1.116$; df $=549 ; p=0.265)$. The appropriate equations are: for female $\log W=3.006 \times \log \mathrm{SL}-4.548$; $r^{2}=0.987$; for males $\log \mathrm{W}=3.051 \times \log \mathrm{SL}-$ $4.618 ; r^{2}=0.987$. However, seasonal variation in slope values was noted for females $\left(F_{4 ; 276}=3.311\right.$; $P=0.0206)$ but not for males $\left(F_{4 ; 261}=0.511\right.$; $P=0.6744)$. It was due to a positive allometric relationship in spring and negative one in winter observed only for females (Table 3). 
Table 1 Year of hatching, number of specimens (n), mean standard length (SL) in mm at capture, mean back-calculated lengths-atage, standard error (SE) and mean annual growth increments for Amur sleeper (sexes combined, juveniles, females and males)

\begin{tabular}{|c|c|c|c|c|c|c|c|c|c|}
\hline \multirow[t]{2}{*}{ Year class } & \multirow[t]{2}{*}{$n$} & \multirow[t]{2}{*}{ SL at capture (SE) } & \multicolumn{7}{|c|}{ Back-calculated body lengths at age } \\
\hline & & & Age 1 & Age 2 & Age 3 & Age 4 & Age 5 & Age 6 & Age 7 \\
\hline \multicolumn{10}{|c|}{ Sexes combined } \\
\hline 2004 & 23 & $52.8(0.9)$ & $38.5(1.0)$ & & & & & & \\
\hline 2003 & 12 & $61.0(2.5)$ & $33.7(2.6)$ & $49.3(2.6)$ & & & & & \\
\hline 2002 & 13 & $72.8(1.8)$ & $31.5(2.1)$ & $49.5(2.3)$ & $63.3(2.0)$ & & & & \\
\hline 2001 & 20 & $83.5(1.7)$ & $36.5(1.2)$ & $51.3(1.3)$ & $64.8(1.5)$ & $76.3(1.5)$ & & & \\
\hline 2000 & 34 & $93.5(1.7)$ & $36.8(1.1)$ & $51.5(1.2)$ & $66.4(1.3)$ & $77.6(1.4)$ & $88.1(1.6)$ & & \\
\hline 1999 & 9 & $118.7(4.2)$ & $41.6(3.1)$ & $59.7(3.1)$ & $77.3(3.9)$ & $91.1(4.7)$ & $102.5(4.8)$ & $114.2(4.0)$ & \\
\hline 1998 & 5 & $121.8(6.5)$ & $40.8(4.3)$ & $57.0(5.1)$ & $75.0(5.2)$ & $88.3(5.5)$ & $100.6(5.5)$ & $110.6(5.5)$ & $121.8(6.5)$ \\
\hline \multicolumn{3}{|c|}{ Mean lengths at age } & $36.7(0.7)$ & $52.0(0.8)$ & $67.2(1.0)$ & $79.8(1.3)$ & $92.1(1.8)$ & $113.0(3.1)$ & $121.8(6.5)$ \\
\hline \multicolumn{3}{|c|}{ Mean SL increment (mm) } & 15.3 & 15.2 & 12.6 & 12.3 & 8.9 & 8.8 & \\
\hline \multicolumn{10}{|l|}{ Juveniles } \\
\hline 2005 & 19 & $37.2(1.2)$ & & & & & & & \\
\hline \multicolumn{10}{|l|}{ Females } \\
\hline 2004 & 11 & $53.0(1.4)$ & $36.6(1.3)$ & & & & & & \\
\hline 2003 & 7 & $60.7(3.3)$ & $27.4(1.0)$ & $46.2(3.0)$ & & & & & \\
\hline 2002 & 9 & $71.7(2.4)$ & $27.9(1.7)$ & $46.1(2.4)$ & $61.5(2.5)$ & & & & \\
\hline 2001 & 7 & $79.6(1.9)$ & $30.7(1.5)$ & $45.7(1.4)$ & $59.9(1.9)$ & $72.8(1.5)$ & & & \\
\hline 2000 & 23 & $94.9(2.4)$ & $33.9(1.1)$ & $49.9(1.4)$ & $66.2(1.7)$ & $78.4(1.8)$ & $90.4(1.9)$ & & \\
\hline 1999 & 8 & $119.1(4.8)$ & $39.9(2.9)$ & $59.2(3.4)$ & $77.4(4.4)$ & $91.8(5.3)$ & $103.6(5.3)$ & $115.1(4.4)$ & \\
\hline 1998 & 5 & $121.8(6.5)$ & $40.8(4.3)$ & $57.0(5.1)$ & $75.0(5.2)$ & $88.3(5.5)$ & $100.6(5.5)$ & $110.6(5.5)$ & $121.8(6.5)$ \\
\hline \multicolumn{3}{|c|}{ Mean lengths at age } & $33.8(0.8)$ & $50.2(1.1)$ & $67.1(1.4)$ & $81.1(1.8)$ & $94.7(2.1)$ & $113.4(3.3)$ & $121.8(6.5)$ \\
\hline \multicolumn{3}{|c|}{ Mean SL increment (mm) } & 16.4 & 16.9 & 14.0 & 13.6 & 18.7 & 8.4 & \\
\hline \multicolumn{10}{|l|}{ Males } \\
\hline 2004 & 12 & $52.7(1.2)$ & $40.2(1.5)$ & & & & & & \\
\hline 2003 & 5 & $61.4(4.3)$ & $42.5(3.2)$ & $53.8(4.1)$ & & & & & \\
\hline 2002 & 4 & $75.3(2.1)$ & $39.6(2.8)$ & $57.1(2.6)$ & $67.3(2.5)$ & & & & \\
\hline 2001 & 13 & $85.5(2.3)$ & $39.7(0.8)$ & $54.4(1.2)$ & $67.5(1.7)$ & $78.1(2.1)$ & & & \\
\hline 2000 & 11 & $90.6(1.9)$ & $42.8(1.3)$ & $54.9(2.0)$ & $66.7(2.1)$ & $75.9(2.2)$ & $83.3(2.1)$ & & \\
\hline 1999 & 1 & 115.0 & 55.9 & 64.4 & 77.0 & 85.5 & 93.9 & 106.6 & \\
\hline \multicolumn{3}{|c|}{ Mean lengths at age } & $41.2(0.8)$ & $55.1(1.0)$ & $67.5(1.2)$ & $77.5(1.5)$ & $84.2(2.1)$ & 106.6 & \\
\hline \multicolumn{3}{|c|}{ Mean SL increment (mm) } & 13.9 & 12.4 & 10.0 & 6.7 & 22.4 & & \\
\hline
\end{tabular}

The overall means by age class and their SE were calculated from whole data set. Differences in means back calculated SL between sexes were analysed with the $t$-test

\section{Reproduction}

At the beginning of April, the average females gonadosomatic index (GSI) was 8.3\% (range from 4.1 to 13.6), for males it was much lower, $1.1 \%$ on average (range from 0.59 to 1.9). Female GSI in April was correlated with fish size $(\log$ GSI $=0.647 \times \log$
SL $\left.-0.569 ; r^{2}=0.50 ; P<0.002\right)$. Male GSI in the same period was not significantly correlated with $\mathrm{SL}\left(\log \mathrm{GSI}=0.009 \times \log \mathrm{SL}-0.309 ; r^{2}=0.22\right.$; $P=0.17)$. For both sexes, GSI reached the highest values from April to August (Fig. 1). However, in these months, we observed large differences between minimal and maximal values of GSI, and apart of 
Table 2 Estimation of von Bertalanffy (VBGF) and Gompertz (GGF) parameters and their asymptotic standard errors (SE) for the Amur sleeper population in the Włocławski Reservoir

\begin{tabular}{|c|c|c|c|c|c|c|}
\hline & \multicolumn{2}{|l|}{ Females } & \multicolumn{2}{|l|}{ Males } & \multicolumn{2}{|c|}{ Sexes combined } \\
\hline & & SE & & SE & & SE \\
\hline \multicolumn{7}{|c|}{ VBGF } \\
\hline$n$ & 278 & & 147 & & 425 & \\
\hline$L_{\text {inf }}$ & 181.5 & 14.9 & 141.1 & 12.3 & 181.5 & 12.8 \\
\hline$k$ & 0.137 & 0.018 & 0.149 & 0.023 & 0.125 & 0.014 \\
\hline$t_{0}$ & -0.403 & 0.085 & -1.285 & 0.140 & -0.715 & 0.076 \\
\hline$r^{2}$ & 0.951 & & 0.974 & & 0.957 & \\
\hline \multicolumn{7}{|c|}{ GGF } \\
\hline$n$ & 28 & & 21 & & 49 & \\
\hline$W_{0}$ & 0.228 & 0.215 & 1.535 & 5.622 & 0.674 & 0.325 \\
\hline$G$ & 6.246 & 0.640 & 9.166 & 94.310 & 6.057 & 0.442 \\
\hline$g$ & -0.285 & 0.070 & -0.066 & 0.927 & -0.172 & 0.054 \\
\hline$r^{2}$ & 0.938 & & 0.938 & & 0.942 & \\
\hline
\end{tabular}

April, GSI was not related to the fish size $\left(r^{2}\right.$ varied between 0.01 and $0.04 ; P>0.1)$. Only larger females had relatively high values of GSI in August (Fig. 1), while gonads of small ones were empty.

At the beginning of the reproductive period (in April) the mean fecundity ( $\mathrm{Fa})$, was 7,766 eggs per female and ranged from 1,963 (at $48 \mathrm{~mm} \mathrm{SL}$ ) to 23,479 (at $129 \mathrm{~mm} \mathrm{SL}$ ). It was correlated with female size as in formula $\mathrm{Fa}=0.2539 \mathrm{SL}^{2.1594} ; r^{2}=0.82$. At the end of the spawning season in August only larger females still had relatively high fecundity with maximum $\mathrm{Fa}=9149$ for a female $139 \mathrm{~mm}$ SL. In contrast, relative fecundity $(\mathrm{Fw})$, relating number of eggs to female weight, actually decreased with fish length $\quad\left(\mathrm{FW}=654.19 \times \mathrm{SL}-3.857 ; \quad r^{2}=0.40 ;\right.$ $P<0.001)$.
The egg diameter histograms revealed two sizegroups of oocytes in gonads: small $0.1-0.9 \mathrm{~mm}$ and large $1.0-1.8 \mathrm{~mm}$ (Fig. 2). It can be related to multiple spawning with at least two egg laying episodes. There were no large oocytes in ovaries from September to April. The highest percentage abundance of large oocytes was found in late April, when this fraction of eggs constituted $40 \%$ of all oocytes in ovaries.

The females matured at the age $1+$, at the standard length of $52.4 \mathrm{~mm}$ on average. The smallest male with well developed gonads was found in June during the reproductive season (57 $\mathrm{mm} \mathrm{SL}$ ). The length structure of males and females during spawning (Fig. 3) showed that males smaller than $55 \mathrm{~mm} \mathrm{SL}$ (the back calculated length at age 2) constituted only $3.2 \%$ of all males that were sampled in that period and their gonads were immature. Females of similar size were more frequently found and more than half of them $(70 \%)$ had matured gonads.

Considering the GSI values (Fig. 1) and oocyte size distribution (Fig. 2), it can be said that spawning in the Włocławski Reservoir lasted from April to end of August.

\section{Discussion}

Literature data show that the growth rates of Amur sleeper vary considerably in its geographic range (Table 4). Such a large variation in growth is a common phenomenon in widely distributed fish species (Mann, 1991) observed as well inside native area, e.g., in dace Leuciscus leuciscus (Lobon-Cervia et al., 1996) as in newly colonized places, e.g., in

Table 3 Seasonal variation in weight-length relationship of Amur sleeper males and females in the Włocławski Reservoir

\begin{tabular}{llllllllll}
\hline Sex & Season & $a$ & SE $a$ & $b$ & SE $b$ & $r^{2}$ & $n$ & $t$ \\
\hline F & Spring & -4.797 & 0.072 & 3.128 & 0.037 & 0.986 & 100 & 3.436 & 0.001 \\
& Summer & -4.374 & 0.096 & 2.915 & 0.050 & 0.989 & 40 & 1.693 & 0.099 \\
& Autumn & -4.601 & 0.066 & 3.039 & 0.035 & 0.990 & 81 & 1.107 & 0.272 \\
& Winter & -4.331 & 0.057 & 2.896 & 0.031 & 0.993 & 63 & 3.359 & 0.001 \\
M & Spring & -4.751 & 0.141 & 3.111 & 0.073 & 0.957 & 82 & 1.507 & 0.136 \\
& Summer & -4.646 & 0.132 & 3.076 & 0.070 & 0.972 & 57 & 1.090 & 0.280 \\
& Autumn & -4.675 & 0.115 & 3.084 & 0.062 & 0.973 & 72 & 1.357 & 0.179 \\
& Winter & -4.316 & 0.128 & 2.891 & 0.067 & 0.971 & 58 & 1.627 & 0.109 \\
& & & & & & & & &
\end{tabular}

Differences in slope $(b=3)$ are tested $(t$ test $)$ 
Fig. 1 Mean

gonadosomatic index and maximum and minimum values over the year for female $n=263$ and male $n=121$ in different length classes corresponding with age groups. $S$ small $1+$, $2+$ (females and males $<69 \mathrm{~mm} \mathrm{SL}$ ); $M$ medium $3+$, 4+ (females 70-85 mm SL; males 70-90 mm SL); $L$ large $5+, 6+$ (females > $85 \mathrm{~mm} \mathrm{SL}$; males $>90 \mathrm{~mm} \mathrm{SL}$ )
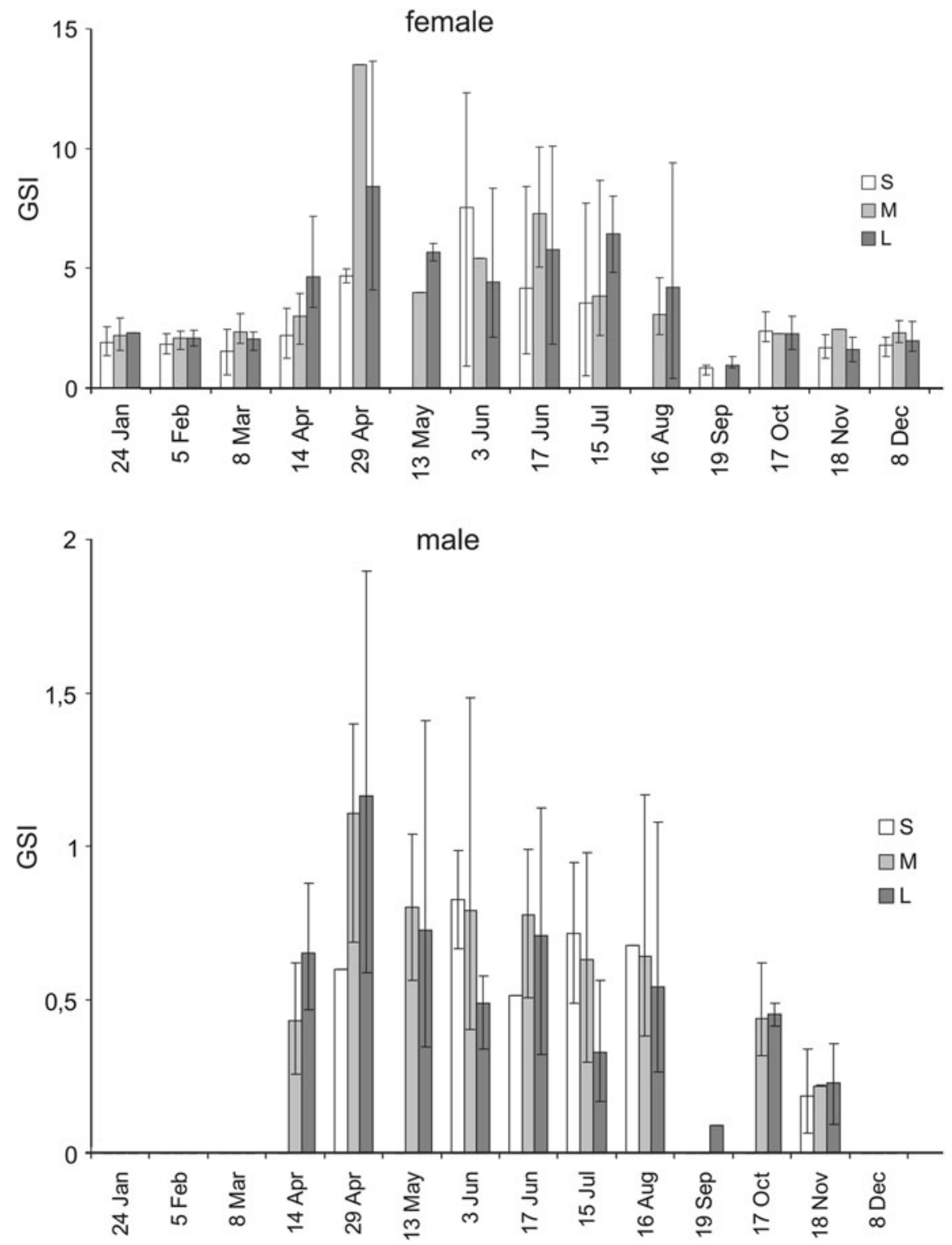

pumpkinseed Lepomis gibbosus (Villeneuve et al., 2005). In case of the Amur sleeper, the von Bertalanffy growth model was successfully fitted only for the Włocławski Reservoir population, but not for the other published data, what restricted the further comparisons among populations within range of distribution. However, analysis of growth curves including the observed SL revealed that in the reservoir, from age class $2+$ onwards, the Amur sleeper grew slower than in other locations (Fig. 4). Generally, the species exhibits superior growth in introduced than in native water bodies (Fig. 4;
Table 4). This discrepancy was especially visible in older age groups, i.e., $3+$ and $4+$. It is likely due to differences in climate, food resources, density dependent factors, etc. The influence of these factors was noted in both native and introduced location in the former Soviet Union (Bogutskaya \& Naseka, 2002). On the contrary, although the species growth rate in the Włocławski Reservoir was lower than in others places, its life span was one of the longest recorded in that the 7-year-old specimens found are 3-4 years older than the maximum age recorded in many other populations (Table 4). Individuals older than $4+$ 

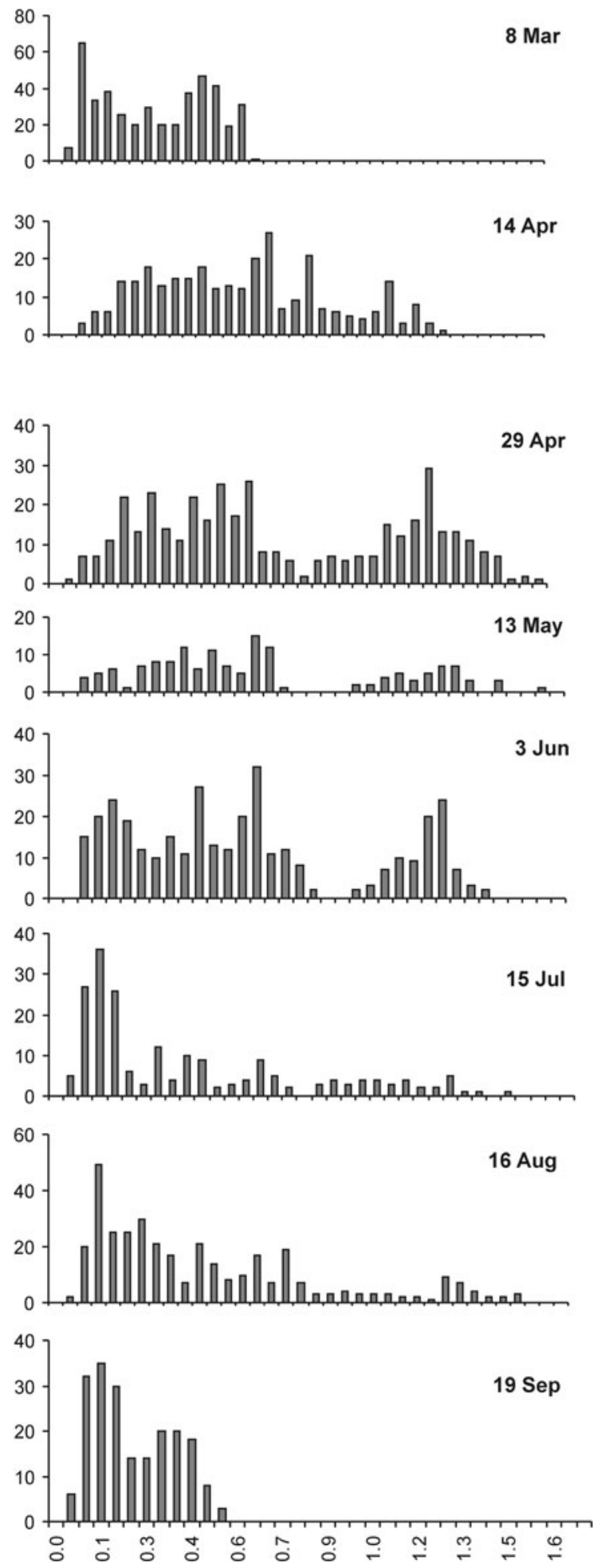

Fig. 2 Size-frequency distribution of oocyte diameter in Amur sleeper gonads from the Włocławski Reservoir were either very rare or not recorded at all, both in its natural range (Kirpichnikov, 1945; Berg, 1949; Nikolsky, 1956) and introduced areas (Spanovskaya et al., 1964; Koščo et al., 2003b; Dgebuadze \& Skomorokhov, 2005). However, in Lake Glubokoe the species was reported to live up to 10 years and to reach a TL of $250 \mathrm{~mm}$ (Reshetnikov, 2001). Litvinov \& O'Gorman (1996) also distinguished seven age classes in the Selenga River (the Baikal drainage).

The year of hatching of the oldest (7+) individual in samples from the Włocławski Reservoir, i.e. 1998, coincided with the first documented records of this species in this water body, when a few specimens were found in two localities (Kakareko, 1999). One year earlier, it was also found in an oxbow lake in the Vistula River in close vicinity of the reservoir's back water (Kostrzewa et al., 1999).

The most numerous age group was $5+(26 \%$ of all collected specimens) followed by $4+(20 \%)$. Usually, the abundance of subsequent generations declines with age. Populations of Amur sleeper dominated by one cohort were observed in many lakes in former Soviet Union as a result of one especially successful reproductive season (Bogutskaya \& Naseka, 2002). The domination of age 5+ individuals in the Włocławski Reservoir can be partly explained by optimal local conditions observed in the year they were produced. Year 2000 had abnormally warm winter months in the period 1994-2007. It probably positively influenced overwinter survival of YOY from this year-class.

Although the Amur sleeper grew relatively slowly in the Włocławski Reservoir (Table 4), its increment in the first year of life was comparable to that of other introduced areas and higher than in its natural range (Fig. 4). Such an accelerated growth rate allows these fish to mature early (e.g., Hutchings, 1993; Fox, 1994; Tarkan, 2006). The female age of maturation $1+$ found in the studied reservoir is earlier than that observed in its natural range $(2+, 3+)$ (Kirpichnikov, 1945; Nikolsky, 1956) as well as in most introduced areas (Spanovskaya et al., 1964; Litvinov and O'Gorman, 1996), where fish matured at the age $2+$, although specimens maturing in the second year of life were also found. Interestingly, length at maturation in the Włocławski Reservoir is similar to that reported elsewhere, despite the differences in 
Fig. 3 Length structure of females $(n=130)$ and males $(n=123)$ during spawning season in the Włocławski Reservoir. Horizontal lines indicate the standard length at age $1+$, $2+, 3+, 4+, 5+$, and $6+$

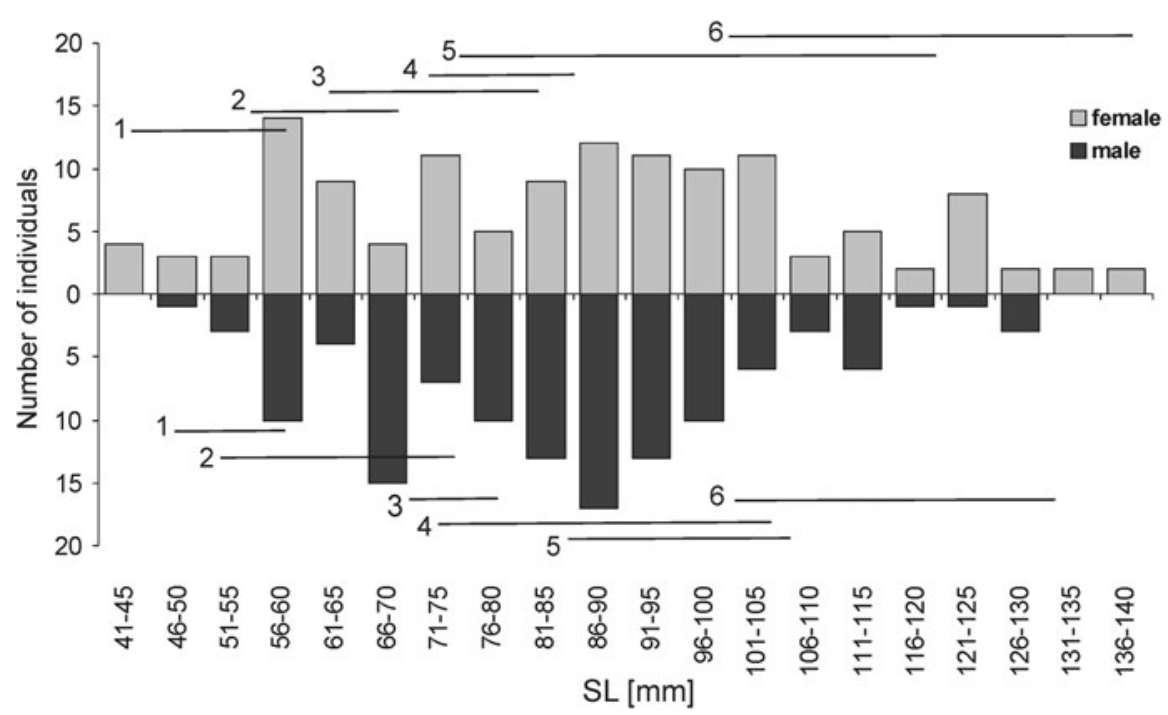

age at maturity (e.g., 50-60 mm for the natural range (Kirpichnikov, 1945; Nikolsky, 1956), while 45-70 mm (Spanovskaya et al., 1964; Pronin \& Litvinov, 1994) and 40-50 mm (Zaloznykh, 1982) in a notnative area in Russia).

Fecundity of the Amur sleeper in the Włocławski Reservoir achieved comparable values with those found in literature (see for review Miller \& Vasil'eva, 2003). However, a comparison of fecundity in nestguarding batch spawners can be unreliable (Fox, 1994). Generally, its fecundity was smaller relative to other freshwater fishes in Poland of similar size not exhibiting parental care. However, it was also higher than native nest-guarders, e.g., gobies (Brylińska, 2000). Moreover, its reproductive success is augmented by specific features of spawning behavior, like a prolonged spawning season and parental care.

The spawning season in the Włocławski Reservoir was longer than that recorded for the Amur sleeper in its natural and introduced range, and lasted almost three months longer than in other regions (Miller \& Vasil'eva, 2003; Bogutskaya \& Naseka, 2002). The duration of the spawning season increases with more favorable water temperature (Bogutskaya \& Naseka, 2002), and the Amur sleeper had optimal spawning conditions in the Włocławski Reservoir. During this time, females appeared to have spawned at least twice. According to Manteifel \& Bastakov (1986), smaller individuals seem to spawn only once. This is consistent with our results, as in August, only large females had high values of GSI and their gonads consisted mainly of large oocytes. Thus, smaller females ended their reproductive season earlier. On the contrary, smaller males probably delayed spawning until later in the season, as only one small male was found in April samples. Our data suggest that spawning was asynchronous, as indicated by high fluctuation of GSI values during this period. Histological studies of gonads showed high variation during the stages of oocyte and sperm development (Travkina, 1997).

The Amur sleeper provides parental care, as males guard their eggs until they hatch, as well as fan the clutch with their pectoral fins and defend the nest aggressively. Parental care appears to be an important component of successful breeding. Such behavior is typical for other successful invaders in Poland and Central Europe, such as topmouth gudgeon (Pseudorasbora parva), Ponto-Caspian gobies (e.g., Neogobius melanostomus, $N$. fluviatilis, N. gymnotrachelus, P. semilunaris), pumpkinseed (Lepomis gibbosus) and brown bullhead (Ameiurus nebulosus), while only five native fishes in Poland build and defend nests as part of their reproductive strategy. While nest guarding increases offspring survival, it is energetically costly. The growth rate differences between females and males found in the Włoclawski Reservoir possibly resulted from unequal investment in reproduction. Analyzing the length structure of Amur sleeper in Włoclawski Reservoir during spawning season we suspect that smaller and younger males almost did not participate in reproduction. Thus, in 
Table 4 Standard lengths (SL) at age of Amur sleeper populations from the study area, native locations and from elsewhere in the introduced range

\begin{tabular}{|c|c|c|c|c|c|c|c|c|c|c|}
\hline \multirow[t]{2}{*}{ Location } & \multirow[t]{2}{*}{ Status } & \multicolumn{7}{|c|}{ Observed SL at age $(\mathrm{mm})$} & \multirow{2}{*}{$\begin{array}{l}\text { Relative } \\
\text { growth } \\
\text { index }\end{array}$} & \multirow[t]{2}{*}{ Source } \\
\hline & & $1+$ & $2+$ & $3+$ & $4+$ & $5+$ & $6+$ & $7+$ & & \\
\hline Vistula River (PL) & Introduced & 37 & 53 & 69 & 83 & 97 & 112 & 122 & 88.8 & Present study \\
\hline Suifun River (RUS) & Native & 32 & 55 & 77 & 85 & 111 & 111 & 136 & 91.5 & $\begin{array}{l}\text { Kirpichnikov } \\
\text { (1945) }\end{array}$ \\
\hline Lower Amur River (RUS) & & 38 & 68 & 100 & 114 & & & & 115.5 & Nikolsky (1956) \\
\hline $\begin{array}{l}\text { Moscow region, natural } \\
\text { waterbodies (RUS) }\end{array}$ & Introduced & 66 & 94 & 110 & 130 & & & & 154.6 & $\begin{array}{l}\text { Spanovskaya et al. } \\
\text { (1964) }\end{array}$ \\
\hline $\begin{array}{l}\text { Moscow region, natural } \\
\text { waterbodies (RUS) }\end{array}$ & & 66 & 90 & 100 & 125 & & & & 148.7 & $\begin{array}{l}\text { Spanovskaya et al. } \\
\text { (1964) }\end{array}$ \\
\hline $\begin{array}{l}\text { Moscow region, natural } \\
\text { waterbodies (RUS) }\end{array}$ & & 55 & 64 & & & & & & 132.2 & $\begin{array}{l}\text { Spanovskaya et al. } \\
\text { (1964) }\end{array}$ \\
\hline $\begin{array}{l}\text { Moscow region, natural } \\
\text { waterbodies (RUS) }\end{array}$ & & 71 & 90 & 120 & 134 & & & & 160.8 & $\begin{array}{l}\text { Spanovskaya et al. } \\
\text { (1964) }\end{array}$ \\
\hline $\begin{array}{l}\text { Moscow region, natural } \\
\text { waterbodies (RUS) }\end{array}$ & & 45 & 66 & 72 & 65 & & & & 99.5 & $\begin{array}{l}\text { Spanovskaya et al. } \\
\text { (1964) }\end{array}$ \\
\hline $\begin{array}{l}\text { Moscow region, natural } \\
\text { waterbodies (RUS) }\end{array}$ & & 60 & 104 & 149 & 151 & & & & 171.1 & $\begin{array}{l}\text { Spanovskaya et al. } \\
\text { (1964) }\end{array}$ \\
\hline $\begin{array}{l}\text { Selenga River (Lake Baikal delta) } \\
\text { (RUS) }\end{array}$ & & 39 & 68 & 94 & 112 & 140 & 167 & 188 & 119.2 & $\begin{array}{l}\text { Litvinov \& } \\
\text { O’Gorman (1996) }\end{array}$ \\
\hline $\begin{array}{l}\text { Lake Glubokoe, Moscow Region } \\
\text { (RUS) }\end{array}$ & & 40 & 70 & 79 & & & & & 112.3 & $\begin{array}{l}\text { Dgebuadze \& } \\
\text { Skomorokhov } \\
(2005)\end{array}$ \\
\hline Moscow region, a pond (RUS) & & 40 & 70 & 91 & 118 & & & & 116.1 & $\begin{array}{l}\text { Dgebuadze \& } \\
\text { Skomorokhov } \\
(2005)\end{array}$ \\
\hline $\begin{array}{l}\text { Lake Glubokoe, Moscow region } \\
\text { (RUS) }\end{array}$ & & 55 & 71 & & & & & & 71.5 & $\begin{array}{l}\text { Dgebuadze \& } \\
\text { Skomorokhov } \\
(2005)\end{array}$ \\
\hline Moscow region, a pond (RUS) & & 50 & 82 & 108 & 122 & 164 & & & 135.7 & $\begin{array}{l}\text { Dgebuadze \& } \\
\text { Skomorokhov } \\
(2005)\end{array}$ \\
\hline Penza Region (RUS) & & 47 & 65 & 96 & 112 & & & & 119.4 & Baklanov (2001) \\
\hline Penza Region (RUS) & & 34 & 63 & 88 & 106 & 149 & & & 109.1 & Baklanov (2001) \\
\hline Leningrad Region (RUS) & & 29 & & 72 & 94 & & & & 66.9 & Kuderskiy (1982) \\
\hline Komi Republic (RUS) & & & 63 & 95 & 111 & & & & 82.1 & Boznak (2004) \\
\hline $\begin{array}{l}\text { Flood plain of Bodrog River near } \\
\text { Somotor River (SK) }\end{array}$ & & 31 & 45 & 62 & 84 & & & & 81.7 & Koščo et al. (2003b) \\
\hline Gusinoe Lake, Baikal basin (RUS) & & & 70 & 110 & 140 & 165 & & & 105.4 & $\begin{array}{l}\text { Bolonev \& Pronin } \\
\text { (2005) }\end{array}$ \\
\hline $\begin{array}{l}\text { Selenga River delta-Murzino } \\
\text { bay, Lake Baikal basin (RUS) }\end{array}$ & & & 60 & 80 & 100 & 120 & & & 79.3 & $\begin{array}{l}\text { Bolonev \& Pronin } \\
\text { (2005) }\end{array}$ \\
\hline Moscow region, a pond (RUS) & & 69 & 87 & 123 & & & & & 162.0 & $\begin{array}{l}\text { Reshetnikov } \\
\text { (unpublished } \\
\text { data) }\end{array}$ \\
\hline Standard growth curve & & 32.8 & 60.1 & 82.8 & 101.9 & 117.7 & 130.9 & 141.9 & & \\
\hline
\end{tabular}




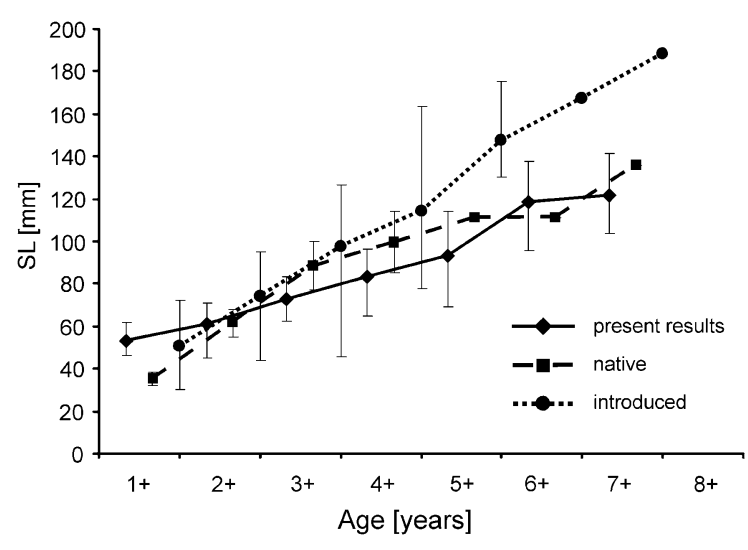

Fig. 4 Observed standard length (SL) at age of the Amur sleeper population from the Włocławski Reservoir (present results) in comparison with average values of SL at age from native and other introduced range, based on Table 4. Vertical lines indicate minimum and maximum SL at age

the first year of life, males grew faster than females that matured at age $1+$ and had to allocate energy earlier from somatic growth to gonad production. As a consequence, up to their third year of life, males were larger than females of the same age. The larger size of the male is also beneficial for a nest-guarding species. First of all, in many cases a larger male is not only a more effective nest defender, but also in some species, large males receive more eggs than small ones (Wiegmann et al., 1992; Mackereth et al., 1999). Secondly, the cost of parental care is high (Smith \& Wootton, 1995) and usually accompanied by weight loss (Berghe, 1992), so smaller males have less reserves to afford it or even may be less likely to recover from such investment (Berghe, 1992; Mackereth et al., 1999). Thirdly, the nest guarding means a decline in food uptake or even starvation (Smith \& Wootton, 1995). The gut fullness coefficients of Amur sleeper males were much lower than females of comparable size range during spawning season in Włocławski Reservoir, while they were similar during the rest of the year. Moreover, during reproductive period, piscivory was recorded only in females, while in later months both sexes preyed on fish with equal frequency (Grabowska et al., unpublished data from the same material as in present studies). Apparently, nest guarding prevents male from chasing such energetically favorable prey.

It has been demonstrated in many cases that reproduction strategy differs between populations and usually new invaded populations show greater reproductive effort than those being established for a longer time (Bøhn et al., 2004; Copp \& Fox, 2007; Fox et al., 2007). Increasing the reproductive effort, usually assessed as increase of GSI, can lead to decreasing the growth rate as a result of the energetic trade off between somatic growth and reproduction (Kozłowski, 1996). In the case of the Amur sleeper, the energetic cost of reproduction cannot be estimated simply by gonad weight. It also includes parental care, early maturation of females, territorial defense, duration of spawning season and number of batches. Thus, the relatively low growth rate of Amur sleeper in the Włocławski Reservoir (Fig. 4) is likely the result of allocation of energy to early reproduction in case of females as well as of maximizing offspring survival by male parental care during prolonged breeding season.

In summary, the Amur sleeper can be described as a relatively small, early maturing species of medium life span, and relatively low fecundity, exhibiting parental care. Similar attributes of life strategies of alien, invasive fish species were found in the Danube (Erös, 2005). Such life-history traits place the species somewhere between opportunistic and equilibrium strategy in a three-point life-history continuum model proposed by and Winemiller \& Rose (1992). The opportunistic strategy maximizes colonizing capacity through early maturity and high reproductive investment in an environment that change frequently or stochastically on relatively small spatial and temporal scales. The equilibrium strategy is more advantageous in stable abiotic conditions with strong direct and indirect biotic interaction, because the species of greater investment in individual offspring through parental care succeed in such more competitive environment. In the light of some recent publications, various alien fish species may enhance their invasive potential through the ability to switch between these life strategies depending on the stage of invasion or on environmental conditions (e.g., Bøhn et al., 2004; Fox et al., 2007; Britton et al., 2008; Kováč et al., 2009; Ribeiro \& Collares-Pereira, 2010).

Acknowledgments We wish to thank dr M. G. Fox for valuable suggestions on the manuscript and language improvement, A. Reshetnikov for help with collection of Russian literature data, J. Gmur, M. Molski, P. Spychalski and Ł. Kapusta for assistance in the field. This article was supported by the Polish Ministry of Science and Higher 
Education project N303 127 32/4022, as well as internal grants form the University of Lodz.

Open Access This article is distributed under the terms of the Creative Commons Attribution Noncommercial License which permits any noncommercial use, distribution, and reproduction in any medium, provided the original author(s) and source are credited.

\section{References}

Antychowicz, J., 1994. Percottus glehni w naszych wodach [Percottus glehni in our waters]. Komunikaty Rybackie 2: 21-22 (in Polish).

Bagenal, T. B. \& F. W. Tesch, 1978. Age and growth. In Bagenal, T. B. (ed.), Methods for Assessment of Fish Production in Fresh Waters. Blackwell, Oxford: 101-136.

Baklanov, M. A., 2001. Goloveshka-rotan Perccottus glenii Dyb. v vodoemakh Permi [Perccottus glenii Dyb. in water bodies of the city of Perm]. Vestnik Udmurtskogo Universiteta. Biology 5: 29-41 (in Russian).

Berg, L. S., 1949. Ryby presnych vod SSSR i sopredelnych stran. Izdatielstvo Akademii Nauk SSSR, Moskva, Leningrad 2: 477-925 (in Russian).

Berghe, E. P., 1992. Parental care and the cost of reproduction in a Mediterranean fish. Behavioral Ecology and Sociobiology 30: 373-378.

Bogutskaya, N. G. \& A. M. Naseka, 2002. Perccottus glenii Dybowski, 1877. Freshwater Fishes of Russia, Zoological Institute RAS [available on internet at http://www.zin.ru/ Animalia/Pisces/eng/taxbase_e/species_e/perccottus/ perccottus_e.htm.

Bøhn, T., O. T. Sandlund, P. A. Amundsen \& R. Primicerio, 2004. Rapid changing life history during invasion. Oikos 106: $138-150$.

Bolonev, E. M. \& N. M. Pronin, 2005. Osobennosti razmernowozrastnoy i polovoy struktury lokalnykh populyatsiy rotana Perccottus glenii Dybowski (Perciformes: Eleotridae) v vodoemakh i vodotokakh basseyna ozera Baikal. Vestnik BGU Seria Biologiya, Izdatielstvo Buriatskogo gosuniversita, Ulan-Ude 7: 138-144 (in Russian).

Boznak, E. I., 2004. Goloveshka-rotan Perccottus glenii (Eleotridae) iz basseyna reki Vychegda [The Amur Sleeper Perccottus glenii (Eleotridae) from the Vychegda River Basin]. Voprosy Ikhtiologii 44: 712-713.

Britton, J. R., G. D. Davies \& M. Brazier, 2008. Contrasting life history traits of invasive topmouth gudgeon (Pseudorasbora parva) in adjacent ponds in England. Journal of Applied Ichthyology 24: 694-698.

Brylińska, M. (ed.), 2000. Ryby słodkowodne Polski [The Freshwater Fishes of Poland]. PWN, Warsaw (in Polish).

Copp, G. H. \& M. G. Fox, 2007. Growth and life-history traits of introduced pumpkinseed (Lepomis gibbosus) in Europe, and the relevance to its potential invasiveness. In Gherardi, F. (ed.), Biological Invaders in Inland Waters: Profiles, Distribution, and Threats. Springer, Dordrecht: 289-306.
Copp, G. H., P. G. Bianco, N. G. Bogutskaya, T. Erös, I. Falka, M. T. Ferreira, M. G. Fox, J. Freyhof, R. E. Gozlan, J. Grabowska, V. Kováč, R. Moreno-Amich, A. M. Naseka, M. Peňáz, M. Povž, M. Przybylski, M. Robillard, I. C. Russell, S. Stakènas, S. Šumer, A. Vila-Gispert \& C. Wiesner, 2005. To be, or not to be, a non-native freshwater fish? Journal of Applied Ichthyology 21: 242-262.

DeMaster, D. P., 1978. Calculation of the average age of sexual maturity in marine mammals. Journal of the Fisheries Research Board of Canada 35: 912-915.

Dgebuadze, Y. Y. \& M. O. Skomorokhov, 2005. Nekotorye dannye po obrazu zhizni rotana Perccottus glenii Dyb. (Odontobutidae, Pisces) ozernoy i prudovoy populyatsii. [Some data on the mode of life of Amur sleeper Perccottus glenii Dyb. (Odontobutidae, Pisces) of lacustrine and pond populations] Trudy Gidrobiologichnoy stantsii na Glubokom ozere [Proceedings of Hydrobiological Station "Lake Glubokoe"]. KMK, Moscov 9: 212-231.

Erős, T., 2005. Life-history diversification in the Middle Danubian fish fauna-a conservation perspective. Archiv für Hydrobiologie (Suppl. 158, Large Rivers) 16: 289-304.

Fox, M. G., 1994. Growth, density and inter-specific influences on pumpkinseed sunfish life histories. Ecology 75: 1157-1171.

Fox, M. G., A. Vila-Gispert \& G. H. Copp, 2007. Life-history traits of introduced Iberian pumpkinseed Lepomis gibbosus relative to native populations. Can differences explain colonization success? Journal of Fish Biology 71(Supp1 D): 56-69.

Francis, R. I. C. C., 1990. Back-calculation of fish length: a critical review. Journal of Fish Biology 36: 883-902.

Gayanilo, F. C., P. Sparre \& D. Pauly, 1994. The FAO-ICLARM Stock Assessment Tools (FiSAT) user's guide. FAO Computerized Information Series, Rome.

Grabowska, J., M. Grabowski, D. Pietraszewski \& J. Gmur, 2009. Non-selective predator-versatile diet of Amur sleeper (Perccottus glenii Dybowski, 1877) in the Vistula River (Poland), a newly invaded ecosystem. Journal of Applied Ichthyology 25: 451-459.

Harka, Á., 1998. New fish species in the fauna of Hungary: Perccottus glehni Dybowski, 1877. Halászat 91: 32-33 (in Hungarian with English summary).

Hickley, P. \& K. F. Dexter, 1979. A comparative index for quantifying growth in length of fish. Fisheries Management 10: 147-151.

Hutchings, J. A., 1993. Adaptive life histories effected by agespecific survival and growth-rate. Ecology 74: 673-684.

Jurajda, P., M. Vassilev, M. Polačik \& T. Trichkova, 2005. A first record of Perccottus glenii (Perciformes: Odontobutidae) in the Danube River in Bulgaria. Acta Zoologica Bulgarica 58(2): 279-282.

Kakareko, T., 1999. Perccottus glenii (Odontobutidae)—nowy gatunek ryby w Zbiorniku Włocławskim na Dolnej Wiśle [Perccottus glenii (Odontobutidae)—in the Włocławek Dam Reservoir on the lower Vistula River]. Przegladd Zoologiczny 42: 107-110 (in Polish with English summary).

Kautman, J., 1999. Perccottus glenii Dybowski, 1877 vo vodách východného Slovenska. [Perccottus glenii Dybowski 1877 from East Slovakian water bodies] Chránené územia Slovenska 40: 20-22 (in Slovak). 
Kirpichnikov, V. S., 1945. Biology of Percottus glehni Dyb. (Eleotridae) and possibilities of its utilization in the control of encephalitis and malaria. Byulleten' Moskovskogo Obshchestva Ispytatelei Prirody. Otdel Biologicheskiy [Bulletin of the Moscow Society of Naturalists. Biological Section] 50 (5-6): 14-27.

Koščo, J., P. Košuth \& E. Hrtan, 1999. Further new fish element of fishes in Slovakia: Amur sleeper. Polovnictvo a Rybárstvo 51(6): 33.

Koščo, J., S. Lusk, K. Halačka \& V. Luskova, 2003a. The expansion and occurrence of Amur sleeper (Perccottus glenii) in eastern Slovakia. Folia Zoologica 52(3): 329-336.

Koščo, J., P. Manko, K. Halačka \& I. Ondrey, 2003b. Vek a rast býčkovca hlavatého (Perccottus gleni Dybowski, 1877) v inudačných vodach Bodrogu. [Growth of Amur sleeper (Perccottus gleni Dybowski, 1877) in the inundation waters of the Bodrog River]. Natura Carpatica 44: 267-274.

Kostrzewa, J., L. Marszał \& K. Tłoczek, 1999. Czy trawianka Percottus glenii ma szanse stać się trwałym elementem polskiej ichtiofauny? [Does Amur sleeper Percottus glenii have a chance to become a permanent element of Polish ichthyofauna]. Chrońmy Przyrodę Ojczystą 5: 98-101 (in Polish).

Kováč, V., G. H. Copp \& R. P. Sousa, 2009. Life-history traits of invasive bighead goby Neogobius kessleri (Günther, 1861) from the middle Danube River, with a reflection on which goby species may win the competition. Journal of Applied Ichthyology 25: 33-37.

Kozłowski, J., 1996. Optimal allocation of resources explains interspecific life-history pattern in animals with indeterminate growth. Proceedings of the Royal Society of London B 263: 559-566.

Kuderskiy, L. A., 1982. Percottus glehni in ponds of Leningrad region. Sbornik Nauchnykh Trudov Gosudarstvennyi Nauchno-Issledovatel'skiy Institut Ozernogo i Rechnogo Rybnogo Khozyaystva 191: 70-75 (in Russian).

Litvinov, A. G. \& R. O'Gorman, 1996. Biology of Amur Sleeper (Perccottus glehni) in the Delta of the Selenga River, Buryatia, Russia. Journal of Great Lakes Research 22(2): 370-378.

Lobon-Cervia, J., Y. Dgebduadze, C. G. Utrilla, P. A. Rincón \& C. Granado-Lorencio, 1996. The reproductive tactics of dace in central Siberia: evidence for temperature regulation of the spatio-temporal variability of its life history. Journal of Fish Biology 48: 1074-1087.

Mackereth, R. W., D. I. G. Noakes \& M. S. Ridgway, 1999. Size based variation in somatic energy reserves and parental care expenditure by male smallmouth bass, Micropterus dolomieu. Environmental Biology of Fishes 56: 263-275.

Mann, R. H. K., 1991. Growth and production. In Winfield, I. J. \& J. S. Nelson (eds), Cyprinid Fishes. Systematics, Biology and Exploitation. Chapman \& Hall, London: 446-481.

Mann, R. H. K., C. A. Mills \& D. T. Crisp, 1984. Geographical variation in the life history tactics of some species of freshwater fish. In Potts, G. W. \& R. J. Wootton (eds), Fish Reproduction. Strategies and Tactics. Academic Press, London: 171-186.
Manteifel, Y. B. \& V. A. Bastakov, 1986. Percottus glehnii Dybowski-a new colonizer in the ichthyofauna of Lake Glubokoe. Hydrobiologia 141: 133-134.

Miller, P. \& E. D. Vasil'eva, 2003. Perccottus glenii Dybowsky 1877. In Miller, P. J. (ed.), The Freshwater Fishes of Europe. Vol. 8/I Mugilidae, Atherinidae, Atherionopsidae, Blennidae, Odontobutidae, Gobiidae 1. AULA-Verlag: 135-156.

Moreau, J., A. Belaud, F. Dauba \& A. Nelva, 1985. A model for rapid growth evaluation in fishes: the case of the cyprinids of some large French rivers. Hydrobiologia 120: 225-227.

Movchan, Y. V., 1989. The first record of Perccottus glehni Dybowski (Pisces, Eleotridae) in the water bodies of the Ukraine. Vestnik Zoologii 5: 87.

Munro, J. L. \& D. Pauly, 1983. A simple method for comparing the growth of fish and invertebrates. Fishbyte 1: 5-6.

Nalbant, T., K. Battes, F. Pricope \& D. Ureche, 2004. First record of Amur sleeper Perccottus glehni (Pisces: Perciformes: Odontobutidae) in Romania. Travaux du Museum National d'Histoire Naturelle 'Grigore Antipa' 47: 279-284.

Nikolsky, G. V., 1956. Ryby basseyna Amura. Itogi Amurskoy Ikhthyologicheskoy Ekspedicii 1944-1949. Izdatielstvo Akademii Nauk SSSR, Moskva: 1-551 (in Russian).

Orlova, M. I., I. V. Telesh, N. A. Berezina, A. E. Antsulevich, A. A. Maximov \& L. F. Litvinchuk, 2006. Effects of nonindigenous species on diversity and community functioning in the eastern Gulf of Finland (Baltic Sea). Helgoland Marine Research 60: 98-105.

Pronin, N. M. \& A. G. Litvinov, 1994. Ecology of Perccottus glehnii Dybowski-exotic invader of Baikal Region. In Baikal as Natural Laboratory for Global Changes. International Workshop. Abstract. Lisna Publishers, Irkutsk 5: 27-28.

Reshetnikov, A. N., 2001. Vliyanie introducyovannoy ryby rotana Perccottus glenii (Odontobutidae, Pisces) na zemnovodnykh $\mathrm{v}$ malykh vodoemakh Podmoskovya. [Influence of introduced fish Percottus glenii (Odontobutidae, Pisces) on amphibians in small waterbodies of Moscow Region]. Zhurnal Obshchey Biologii 62 (4): 352-361 (in Russian).

Reshetnikov, A. N., 2004. The fish Perccottus glenii: history of introduction to western regions of Eurasia. Hydrobiologia 522: 349-350.

Ribeiro, F. \& M. J. Collares-Pereira, 2010. Life-history variability of non-native centrarchids in regulated river systems of the lower Guardiana River drainage (south-west Iberian Peninsula). Journal of Fish Biology 76: 522-537.

Rice, A. A. \& D. F. Sax, 2005. Testing fundamental evolutionary question at large spatial and demographic scale: species invasion as an underappreciated tool. In Sax, D. F., J. J. Stachowicz \& S. D. Gaines (eds), Species Invasions: Insights into Ecology, Evolution and Biogeography. Sinauer Associates, Sunderland: 291-308.

Ricker, W. E., 1975. Computation and interpretation of biological statistics of fish populations. Fisheries Research Board of Canada Bulletin 191: 1-382.

Šipoš, Š., B. Miljanović \& L. J. Pelčić, 2004. The first record of Amur sleeper (Perccottus glenii Dybowsky, 1877, fam, Odontobutidae) in the Danube River. International Association for Danube Research 35: 509-510. 
Smith, C. \& R. J. Wootton, 1995. The costs of parental care in teleost fishes. Review in Fish Biology and Fisheries 5: $7-22$.

Southwood, T. R. E., 1988. Tactics, strategies and templets. Oikos 52: 3-18.

Spanovskaya, V. D., K. A. Savvaitova \& T. L. Potapova, 1964. Ob izmenchivosti rotana (Perccottus glenii Dyb. fam. Eleotridae) pri akklimatizatsii. [About the variability of Amur sleeper (Perccottus glenii Dyb. fam. Eleotridae) under acclimatization]. Voprosy Ikhtiologii 4: 632-643 (in Russian).

Steinmetz, B. \& R. Müller, 1991. An atlas of fish scales, and other body structures used for age determination: nonsalmonid species found in European fresh waters. Samara Publishing, Cardigan.

Svardson, G., 1949. Natural selection and egg number in fish. Report of the Institute of Freshwater Research Drottningholm 29(1): 15-122.

Tarkan, A. S., 2006. Reproductive ecology of two cyprinid fishes in an oligotrophic lake near the southern limits of their distribution range. Ecology of Freshwater Fish 15: 131-138.

Taylor, C. C., 1962. Growth equation with metabolic parameters. Journal du Conseil International pour l'Exploration de la Mer 27: 270-286.

Terlecki, J. \& R. Pałka, 1999. Occurrence of Perccottus glenii Dybowski 1877 (Perciformes, Odontobutidae) in the middle stretch of the Vistula River, Poland. Archives of Polish Fisheries 7: 141-150.

Travkina, G. L., 1997. Osobennosti oogeneza i dinamiki razvitya ootsitov u rotana-goloveshki Percottus glehni Dyb.
[Characteristics of oogenesis and dynamics of oocytes development of Amur sleeper Percottus glehni] Trudy Biologii Nauchno-Issledovatelnego Instituta 44: 29-38 (in Russian).

Tripple, E. A. \& H. H. Harvey, 1987. Reproductive responses of five white sucker (Catostomus commersoni) populations in relation to lake acidity. Canadian Journal of Fisheries and Aquatic Science 44: 1018-1023.

Villeneuve, F., G. H. Copp, M. G. Fox \& S. Stakėnas, 2005. Interpopulation variation in growth and life-history traits of the introduced sunfish, pumpkinseed Lepomis gibbosus, in southern England. Journal of Applied Ichthyology 21: 275-281.

Vollestad, L. A. \& J. H. L'Abbe-Lund, 1990. Geographic variation in life-history strategy of female roach Rutilus rutilus (L.). Journal of Fish Biology 37: 853-864.

Wiegmann, D. D., J. R. Baylis \& M. H. Hoff, 1992. Sexual selection and fitness variation in a population of smallmouth bass, Micropterus dolomieui (Pisces: Centrarchidae). Evolution 46: 1740-1753.

Winemiller, K. O. \& K. A. Rose, 1992. Patterns of life history diversification in North American fishes: implication for population regulation. Canadian Journal of Fisheries and Aquatic Science 49: 2196-2218.

Zaloznykh, D. V., 1982. Nekatoryie aspekty biologii rotana v vodoemakh Gorkovskoy oblasti. [Some aspects of Amur sleeper biology in water bodies of Gorky Region]. Mezhvuzovskiy sbornik. Nazemnye i vodnye ekosystemy. Gorkiy, Gorkovskiy Universitet 5: 44-47 (in Russian).

Zarr, J. H., 1984. Biostatistical Analysis. Prentice-Hall, Inc., Englewood Cliffs: 718. 